\title{
Corela
}

Cognition, représentation, langage

17-2 | 2019

Vol. 17, $\mathrm{n}^{\circ} 2$

\section{The cognitive motivation and purposes of playful blending in English}

\section{Boris Lefilliâtre}

\section{Q OpenEdition}

1 Journals

\section{Electronic version}

URL: http://journals.openedition.org/corela/9518

DOI: 10.4000/corela.9518

ISSN: 1638-573X

\section{Publisher}

Cercle linguistique du Centre et de l'Ouest - CerLICO

\section{Electronic reference}

Boris Lefilliâtre, "The cognitive motivation and purposes of playful blending in English", Corela [Online], 17-2 | 2019, Online since 30 January 2020, connection on 21 January 2021. URL: http:// journals.openedition.org/corela/9518; DOl: https://doi.org/10.4000/corela.9518

This text was automatically generated on 21 January 2021

\section{(c) (i) (2)(2)}

Corela - cognition, représentation, langage est mis à disposition selon les termes de la licence Creative Commons Attribution - Pas d'Utilisation Commerciale - Partage dans les Mêmes Conditions 4.0 International. 


\title{
The cognitive motivation and purposes of playful blending in English
}

\author{
Boris Lefilliâtre
}

\section{Introduction}

1 A communicative situation typically displays an organisation of simplex and complex words whose formations are based on well-known, familiar morphemes. A simplex word like ball can be defined as a monomorphemic lexeme (Van Der Hulst $2008: 233$ ), as opposed to a complex word commonly referred to as a polymorphemic form (Fuster Márquez $2008: 66$ ). Complex words comprise derivatives, made up of a root to which at least one affix is added, for example with unmanliness in which the root man has been prefixed with un- and suffixed with -ly and -ness (OED Online 2018, s.v. "unmanliness, n.", "unmanly, adj.", "manly, adj."), and unclipped compounds, formed with unclipped words and/or combining forms, such as hotdog (Sanchez-Stockhammer $2018: 27$ ), hydroelectric (Mattiello 2013 : 35), hydrology (Mattiello 2013 : 35) or microscope (Baeskow 2004 : 72). In sharp contrast with its environing text, a playful blend stand out of the discourse here and there.

Blends are atypical words since the morphemic approach to complex and simplex words prevents us from defining them as complex words. A blend may imply a clipped segment called a "splinter", thereby introducing a submorphemic, i.e. non-morphemic element in the combination (Bauer $1983: 234$; Mattiello $2013: 34$ ). ${ }^{1}$ In most cases, more than one splinter is involved, as in camcorder (camera + recorder) ${ }^{2}$ (Bassac 2012:182 ; Mattiello 2013 : 305). The created lexemes that combine back-clipped words, with at least two initial splinters, constitute clipped compounds and "are excluded from the category of blends" (Plag 2003 ; Gries 2004, 2006). These words include sitcom (situation + comedy) (Renner, Maniez, Arnaud 2012:7) or SoLoMo (social + local + mobile) (Beliaeva 2014 : 7). Moreover, this paper focuses on lexical blends, thereby excluding "blending 
errors" (Bertinetto 2001 : 2). Lexical blends are intentional and communicative, whereas blending errors are accidental and caused by "a derailment of the psycholinguistic system without any communicative function or purpose" (Bertinetto $2001: 18$ ). These performance errors are also called slips or lapses (Cannon $1986: 730$, 750). Lexical blending may thus be summarily defined as follows: the intentional combination of two or more elements, shortened by the use of at least one splinter, or two or more splinters which are not all apocoped versions of their base words (as they would be called "clipped compounds"). ${ }^{3}$

Not only are blends outstanding in their context of utterance as they are surrounded by morphemically based words, most of which are simplex words or derivatives, but some specific blends stand out on account of their playfulness.

4 It is claimed that sometimes, blends are likely to be chosen partially at random (Bauer 1983 : 234). This arbitrariness deserves to be mentioned, but it is only partial (Bauer $1983: 234$ ), which means that the use of blending may be multifactorial. The arbitrary part will be left aside so as to concentrate on motivation and purpose. Motivations for blending include morphological transparency (Cannon 2000 : 954) to designate new referents in an explanatory or defining way, so as to fill "a semantic void in the lexicon" (Cannon 2000 : 953). They are "serious coinings, often naming man-made objects, processes, and facilities" (Cannon $1986: 746)$. For the name of the company Groupon (group + coupon) (Eldridge 2011), the use of blending is motivated by the explanatory function of the source words, as the enterprise "groups" together local merchants and subscribers who collect money-off vouchers or "coupons". A situation which has been much dealt with in the news is the withdrawal of the United Kingdom from the European Union, referred to with the blend Brexit (British + exit), right from the evocation of the idea in 2012, and especially with the referendum held in the UK on 23 June 2016 that favoured withdrawal from the EU (OED Online 2018, s.v. "Brexit, n."). Blending may also be motivated by a meliorative way of designating or describing a referent. For instance, the noun of the entertaining enterprise Funimation (fun + animation) (The Freelance Studio 2016) which dubs and distributes foreign animated film, especially Japanese or Japanese-style animes, was produced with the help of the meliorative term fun, thereby enhancing the image of the company with its very name. Concision may be mentioned as another major motivation to blend words. Blending is a denser way of speaking or writing, which "save(s) time and paper in communicating" (Devereux $1984: 210$ ), according to the principles of "least effort" and "cognitive economy" (Mattiello $2013: 27$; Tournier $2004: 162,195$ ), also referred to as "linguistic economy" (Tournier $2004: 161-162)$ regarding the process of clipping inherent to blending. Easiness of written or spoken performance with the help of concision, or "communicative economy" (Grzega, Schöner 2007 : 36 ; Miller 2014 : 84), also motivates blending. The phrase "walking marathon" is occasionally replaced by the blend walkathon (walk + marathon) (Bertinetto 2001:28 ; Bryant 1974:171), or the blend telecast is sometimes conveniently substituted to the longer formula "television broadcast" (Bertinetto 2001 : 28 ; Devereux 1984: 213 ; Mattiello 2013 : 310). The economy may be significant in blends made up of more than two bases: turducken is produced with three etyma (turkey + duck + chicken) (Bassac $2012: 169)$, like affluemza (affluence + influence + feminism) (Bassac $2012: 169$ ), while afflufemza is coined with four items (affluent + feminist + mothers + influenza) (Beliaeva $2014: 7$ ). 
5 The motivation for blending under study in this paper is word play, ${ }_{4}^{4}$ which will be explained in the first part of this paper. Studying playful blending is an efficient way of clarifying the link and distinction between the notions of motivation, purpose, means and end underlying the mechanism of lexicogenesis. The means are embodied by the form of the created word, whereby the word-formation process is essential. The end is twofold: what is often merely called "purpose" corresponds to the intention of the coiner, and motivation is the purpose of the chosen form, i.e. the reasoned nonarbitrary choice to produce a form providing a certain meaning and lexical effect. In accordance with the literature, this paper will refer to the purpose of the chosen form as the "motivation", and designate the purpose of the speaker or writer as such or with synonymous words like "intention", "goal" or "aim", keeping in mind that motivation is oriented to lexical forms, while purpose is oriented to the interlocutors.

6 The motivation and purposes of playful blends will be explicated and exemplified. Furthermore, this paper will examine whether the two concepts can be distinguished with the consideration that motivation would be context-free and purpose contextdependent. In order to inspect this question, different utterances of the same examples of playful blends will be examined, and synonymous forms inside and outside playful blending will be analysed. The blends are selected from a list of examples provided in the literature. This list includes blends which are playful or not, from which are selected playful blends according to the criteria of playfulness which are developed in the first part of this study. Utterances of these blends are found online, so as to illustrate combinations of various motivations in addition to word play, and manifold purposes justifying the use of an atypically non-morphemic playful form in the discourse. Usage variations among coreferential blended words are made explicit with the help of corpora and corpus-based dictionaries, in order to identify different motivations. ${ }^{5}$

\section{The motivation of playful blending}

7 The motivation of playfulness in blending relies on the association of linguistically related source forms. With this definition of the playfulness of specific blends, all blends are not playful. If the outputs airmada (air + armada) (Bryant $1974: 174$ ) and airobics (air + aerobics) (Mattiello 2013 : 303) both play with the common diphthong /eə/ in their etyma, other blends, such as organule (organism + molecule) (Cannon $1986: 731$ ) or Heliport (helicopter + airport) (Connolly $2013: 4$ ) show no morphological or semantic link in their source words ; they are therefore not playful at all.

Blending is considered playful when it is etymologically playful, as well as employed playfully in communication. It excludes the words which are opacified as blends. Some blends are so well-integrated into standard English that people tend to be unaware of their status (O'Grady, Dobrovolsky, Katamba $1996: 158$ ), as they hear or read them like simplex forms. In such cases, they are not (or no longer) playful, even if their source words are linguistically linked. These blends include:

chortle (chuckle + snort) (Algeo $1977: 51$; Bertinetto 2001 : 27 ; Devereux $1984: 214$;

Cannon 2000 : 955 ; Mattiello 2013 : 305 ; O'Grady, Dobrovolsky, Katamba 1996 : 158)

motel (motor + hotel) (Algeo $1977: 52$; Bat-El 1996 : 283 ; Bertinetto $2001: 27$; Cannon

2000 : 954 ; Connolly $2013: 3$; Devereux $1984: 213$; Gries $2004: 415$; Renner,

Maniez, Arnaud $2012: 3)$

bit (binary + digit) (Bertinetto 2001 : 27 ; Devereux 1984 : 213 ; O'Grady, Dobrovolsky, 
Katamba $1996: 158)$

modem (modulator + demodulator) (Mattiello 2013 : 308 ; O'Grady, Dobrovolsky, Katamba 1996 : 158).

9 If a few of them used to be playful originally when they were created, nowadays they cannot be used for word play in so far as their source words are unknown by the users. However playful they can be etymologically, their opacification prevents them from being used playfully.

Word play in blends is a motivation taking root in a linguistic relatedness between the blended source words, but criteria need to be defined for this special relation between the input forms. Blended words from the English language are predictable according to their semantic links (i.e. their playfulness), as Swedish blends are (Ek 2018), and "blend structure is (...) constrained by phonological and semantic considerations" (Lepic 2016), especially regarding playful blending. Mattiello (2014 : 139-140) explains that "the speaker tends to choose two source words which are similar to each other in terms of: 1) phonemic and/or graphemic length and stress pattern, 2) part of speech, and sometimes even 3) semantics (as in fantabulous)", in the "most intentional (coordinate) blends" as well as in "speech-error blends". According to the present definition of word play in blending, only the two lexical elements are retained: morphology and semantics. The syntactic criterion is discarded, on account of the existence of morphologically and/or semantically related source words of different parts of speech in "jumbles", which are described as associating collocatable and semantically related but syntactically diverse bases (Algeo $1977: 58$ ). Thus, the blend numberous (noun number + adjective numerous) (Algeo $1977: 58$; Mattiello $2013: 308$ ) is playful as it associates bases with similar morphological segments, even if their bases belong to different parts of speech, and beermare (noun beer + noun nightmare) (Bertinetto 2001 : 27) is not playful as it associates bases without any morphological or semantic link, even if their bases belong to the same part of speech.

11 Morphological links of source words resulting in playful blends may occur with a common base morpheme, affix or any similarity of sound (Algeo 1977 : 57) or written form. Similarity between the source words fuels the playful character of blends (Gries $2004: 417,419$; Kelly $1998: 586-588$ ). It occurs that the similarity is such that it originates the formation of blends without the need to remove any part of the bases, as in predictionary (prediction + dictionary) (Beliaeva $2014: 17$ ). The base words may have a shared affix (Algeo $1977: 57$ ), for example with the prefix pre- in imperence (impertinence + impudence) (Bertinetto $2001: 27$; Cannon 1986 : 738), or the suffixes -ing in aggranoying (aggravating + annoying) (Mattiello $2013: 303$ ), -er in the competing forms scinter, scrinter and sprinter (scanner + printer) (Bauer, Lieber, Plag $2013: 462$ ) or -ly in prezactly (precisely + exactly) (Arndt-Lappe, Plag $2012: 1$; Bauer, Lieber, Plag $2013: 459)$. Any similarity of sound may be a factor of playful blends. The forms torrible (terrible + horrible) (Gries 2004 : 425 ; Mattiello $2013: 310$ ) and slickery (slicker + trickery) (Bryant $1974: 171)$ indicate that an overlapping morphology between pre-existing words prompts the formation of blends. Sometimes, the playfulness does not rely on a similarity between the bases, but with another "source" word which is homophonous with the output form, as in the pun Maxim-Eyes (maximum + eyes) (Bryant $1974: 166$ ) whose pronunciation is the same as the verb maximize. In puns ${ }^{6}$, is it the graphic and/or the phonological similarity between the source words that prevail(s)? 
12 In puns with a double meaning mixing two perfect homonyms, as in grave meaning both "serious" and "tomb" (Algeo $1977: 50$ ), neither the graphic nor the phonological similarity prevails. For these words, both the graphic and phonemic forms motivate the blending and it is unclear which of the spoken or written form matters most.

13 By contrast, in other playful blends, either the written or the spoken form is of particular importance. In many puns where there is a double meaning, the source words are perfect homophones but imperfect homographs, so that the written form indicates the use of blending and the presence of a double meaning. This is what happens in the following puns:

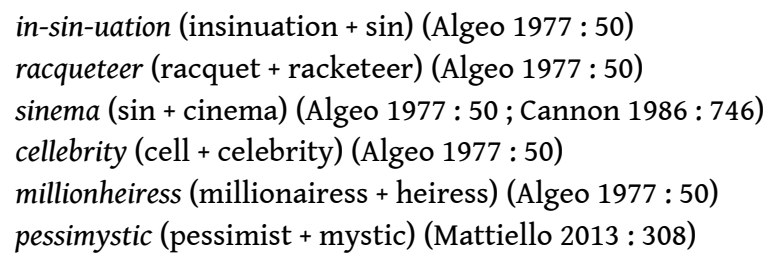

14 In such examples, written forms prevail, sometimes merely through one letter (for sinema) or typography (hence the hyphenation in in-sin-uation). Conversely, it transpires that sound similarity is a motivation for playfully blended words such as peekture (peek + picture) (Bertinetto 2001 : 27 ; Bryant $1974: 181$ ), as it is the proximity in the vowel space positions between short lax /I/ and long tense /i: / that triggers off the blended form. The same holds true for rendezwoo (rendezvous + woo) (Bryant 1974 : 183 ; Mattiello 2013 : 309), with the common /u:/ phoneme written differently in the bases.

Regarding a semantic relation, blends may unite synonymous words. ${ }^{7}$ Many of them are near-synonymous or synonymous adjectival blends (Bassac 2012 : 189-190), like fantabulous (fantastic + fabulous) (Arndt-Lappe, Plag 2012 : 2 ; Bassac 2012 : 190 ; Bertinetto 2001 : 27 ; Mattiello 2013 : 306) or confuzzled (confused + puzzled) (Bassac 2012 : 190 ; Mattiello 2013 : 305). There are also synonymous blends from other parts of speech, like the verbs bonk (bump + conk) and shill (shiver + chill), or the nouns stocks (stockings + socks) and needcessity (need + necessity) (Algeo 1977 : 57). Conversely, some blends are playful because of the oxymoronic relation between their bases. These blends include antonymic pairs, as in frenemy (friend + enemy) (OED Online 2018, s.v. "frenemy, n.") or craptacular (crap + spectacular) (Mattiello 2013 : 305 ; Oxford Dictionaries 2019, s.v. "craptacular"), but not all are playful: antonymic blends like immittance (impedance + admittance) (Cannon $1986: 741$ ), or near-antonymically related source words like compander (compressor + expander) (Cannon 2000 : 955), are technically motivated, the former in the area of electricity and the latter in telecommunications and electronics. Antonymic bases create a playful blend only if they have an oxymoronic relation. Moreover, if the semantic link stems from a mere collocation, as is the case with certain jumbles (a specific sort of blend mentioned previously) such as dumbfound (adjective dumb + verb confound) (Algeo 1977 : 51, 58 ; Mattiello 2013 : 306), there is no word play. All input forms are indeed blended on account of a link between them, but playfulness does not occur for any sort of association. Furthermore, playfulness is limited to linguistic links. Other words are blended because they are linked extralinguistically. A relation may occur between two referents, whose corresponding source words are not related semantically, but pragmatically, in a given communicative situation. They are called "dvandva" blends (Algeo $1977: 57$ ) and the examples provided are gasid indigestion (gas + acid indigestion) (Algeo 1977 : 58), Hungarican (Hungarian + American) (Algeo 1977 : 52 ; Mattiello 2013 : 307) and smog 
(smoke + fog) (Algeo $1977: 50$; Arndt-Lappe, Plag $2012: 2$; Bauer, Lieber, Plag $2013: 459$, 461 ; Bertinetto $2001: 28$; Cannon 2000 : 954 ; Devereux $1984: 213$; Mattiello 2013 : 309). Dvandva blends are here discarded from the category of playful blends.

It may be summarized that word play is circumscribed to source words with an oxymoronic effect or a linguistic similarity (either semantic or morphological); those which present an antonymic relation are playfully blended only if they are used for an oxymoronic effect. As discussed previously, the inputs may include another word than the etyma, when the output blend is homophonous with an existing word, which makes the blend playful. Exploiting recognizable (non-opacified) linguistic relatedness between attested words to blend them constitutes the motivation of the locutor to play on these words. The motivation of playfulness is cognitive as the minds of the interlocutors have to recognize this special relation between two or more source items among pre-existing words.

17 A cognitive remotivation of certain playful (i.e. linguistically related) blends as phonesthetic blends has recently been studied (Smith 2014). This study reinforces Bauer's suggestion (1983: 235) that "the preservation of initial consonant clusters, in other words initial phonesthemes, plays a role in determining the structure of short blend outputs" (Smith $2014: 12$ ). In the area of sound symbolism or "complex iconicity" (Miller 2014 : 155), phonaesthesia is defined as "the network-like association between words sharing partial form and meaning" (cf. De Cuypere $2008: 113$; Miller $2014: 155$ ). This paper falls within this scope, and suggests that playful blends between similar input forms influence the formation of other blends adopting the previously attested blends' consonant clusters to make them phonesthemes, i.e. "sub-morphemic unit(s) that ha(ve) a predictable effect on the meaning of a word as a whole" (Otis ; Sagi 2008 : 65). A case in point is the playful blend blotch (blot + splotch) (Smith $2014: 23,25,26-28$, 38), which probably triggered the coinage of blurt (blow + blare) (Smith $2014: 23,27,38$, 41), thus establishing the existence of the phonestheme bl-containing the idea of breathing or swelling (Drellishak 2006; Smith $2014: 23$; Tournier 1985). In a similar way, slosh (slop + slush) (Smith $2014: 15-16,23,39,41)$ incited the formation of slithy (slimy + lithe) (Smith $2014: 23,39,42)$, on account of a sl-phonestheme bringing about a sense of slowness and sloth (Tournier 1985), or the idea of attack or sliding movement (Reay 2009). Likewise, glaze (gaze + glare) (Smith $2014: 23,38,41$ ) precedes the formation of glob (blob + gob) (Smith $2014: 16,23,39,42)$, adopting a gl- phonestheme related to the notions of light, vision, or light reflecting on a smooth surface (Drellishak 2006 ; Smith $2014: 23$; Tournier 1985). Thus, on the basis of a playful blend, phonesthetically motivated blend-words are formed afterwards, which engenders the remotivation of the previously coined blend as not only playful but also phonesthetic, in accordance with the cognitive and psycholinguistic theory that there is a structured sound symbolism upon which coiners rely to produce novel forms (Smith $2014: 12$ ). The motivation of playful blends may be bidirectional with the help of phonaesthesia.

Playfulness in blending is achieved with the help of a recognizable linguistic relatedness between the source lexemes, taking the form of a morphological similarity, or a semantic link with similar or oxymoronic source items. ${ }^{8}$. The motivation of word play is sometimes doubled afterwards, when speakers or writers associate semantic features to a consonant cluster to coin other blends, thereby remotivating the original playful blend with phonesthesia. As the aim of the form of playful blends has been 
explored, this paper then moves on to the aim(s) of coiners playing with existing words through blending.

\section{The purpose(s) of playful blending}

\subsection{The general purpose of playful blending}

19 The process of playful blending enables the speaker or writer to produce an output form of higher cognitive salience than its environing text. ${ }^{9}$ Like any other blend, playful blends concisely unite two or more words together. This conciseness makes them clearly distinct from their environing words, which are usually simplex forms, derivatives or at worst unclipped compounds. Another reason why these blends stand out is that there is something special about them: a linguistic tie between the source lexical items. Thus, the purpose of cognitive salience is doubly obtained in these forms, stemming from two motivations: the concision of blending in general, and word play in specific blends through the linguistic link between the source lexical items.

Language play and the notion of salience are both considered as motivations in Grzega and Schöner's list (Grzega, Schöner $2007: 36$; Miller $2014: 84$ ), whereas here, language play is a motivation, but salience is defined as a purpose, and the term "salience" is used differently in this list: it is a specific sort of salience called "cultural salience" which is referred to in their work. The notion of salience is employed in discourse semantics and pragmatics usually to explain that some referents are central in the minds of interlocutors. One the one hand, local salience applies to a referent which is remarkable because it has just been mentioned textually, or because it is outstanding in the specific communicative situation by its perceptive (visual, auditory, olfactory, etc.) properties. On the other hand, cognitive salience applies to a referent which is salient because it is the concern of shared knowledge - in this case it is called "cultural salience" (Grzega, Schöner 2007 : 36 ; Miller 2014 : 84) - or common conceptual representations between the communication participants (Neveu 2011a: 311-312 ; Neveu 2011b: 100). However, this paper uses this notion not about a salient referent, but a salient uttered form among others in its environing context.

21 Presented out of their context, playful blends reveal nothing more precise than a higher concision in their formation and a linguistic relation between the source words. However, cognitive salience makes sense in contexts: a heightened cognitive salience makes the form stand out of the discourse. It is worth mentioning playful blends in their context of utterance, in order to identify the reasons why a locutor uses a salient form. Even if the source words are easily recognizable, a higher cognitive difficulty in the reception of the word is established with a blend. The mind of the hearer or reader decomposes the form into the source items to understand an unfamiliar playful blend. A reinforced cognitive salience is materialized by a higher concision, a special relation between the input pre-existing words and the form's novelty. As a result, as the cost of articulation decreases, the cost of cognitive processing increases proportionally, which possibly emphasizes or dissimulates the output form: playful blends may attract the interlocutors' attention on them, or reduce the impact of a form which is understood less directly. The reference stands out or fades away. Below are a few utterances classified according to one specific reason why the author wants to emphasize or diminish the impact of a word, even if they do not constitute clear-cut types: multiple 
purposes often come into play simultaneously, as will be discussed further on (in section 3.2).

\subsection{The particular purposes of playful blending}

\subsubsection{Humour}

One way of being emphatic is humour (Bertinetto $2001: 3$ ). Cannon explains that " $(\mathrm{m})$ ost of the early $20^{\text {th }}$-century blends were jocular or humorous, providing oral and visual puns" (Cannon 1986 : 737). A few possible illustrations are the 1914 blend odditorium (oddity + auditorium) referring to "(a) shop or venue for the display or sale of oddities or oddments" (OED Online 2018, s.v. "odditorium, n."), the 1937 blend philanthropoid (philanthropist + anthropoid) humorously designating a professional philanthropist (Collins English Dictionary 2019, s.v. "philanthropoid" ; OED Online 2018, s.v. "philanthropoid, n. (and adj.)"), or the 1938 blend clientitis (client + tonsillitis) expressing the difficulty of seeking or dealing with clients (OED Online 2018, s.v. "clientitis, n."). The noun jargonaut is also labelled humorous (Cannon 2000 : 956). It designates someone who uses jargon excessively, probably on the model of Argonaut even if this word is not related to argot (Cannon 2000 : 956 ; OED Online 2018, s.v. "Argonaut, n.", "jargonaut, n."). The noun governator (Mattiello 2013 : 307) was jocularly coined when Arnorld Schwarzenegger, who had notoriously been a "Terminator" robot in the cinema, was the governor of California.

Portmanteaus - which are equivalently called associative blends (Algeo $1977: 61$ ) - are claimed to be "originally created for comic effect" (Cannon 1986 : 728). Here are examples of humorous playful portmanteau words.

(1) The subconscious. It is omnipresent, sees everything that you don't, and arguably knows more about who you really are and what you really want than you do... and yet, most of us pay it little mind. Wait, was that a pun? Maybe my subconscious just felt like making a funny... but, I promise, it was punintentional. SCOTT, Justin C, "The Power and Influence of Your Subconscious Mind" (Medium, 2017) (online) <https://medium.com/bigger-picture/the-power-and-influence-ofyour-subconscious-mind-eb3e12c55464>, 01/01/2017.

The blend punintentional is amusing because it is itself a pun expressing the fact that no pun was intended, even though one was made, allegedly unintentionally. This playful word is based on the similarity of the word pun with the prefix of the adjective unintentional. Making a pun while stating that another pun was unintentional creates a humorous effect.

(2) On Tuesday morning in South Korea, a 17-year-old American sent a tweet about her breakfast. Within minutes, it had flown round the world.

"Wish I finished my breakfast sandwich but my stubborn self decided not to," wrote the teenage snowboarder Chloe Kim.

"And now I'm getting hangry."

(...)

"When the brain runs dry of fuel, it stimulates a stress response. It's really a survival mechanism.

(...)

"One of the most common emotions is anger - and that's why, many times, when we become hungry, we become irritable."

Amos, Owen, "Chloe Kim: Why do some people get "hangry'? (BBC, 2019) (online)

$<$ https://www.bbc.com/news/world-us-canada-43050394>, 01/01/2017. 
The two source words hungry and angry share the phonological segment /ygrI/ and grapheme <ngry> on which the pun is based.

(3) If you've got a cat I'm sure you've heard it make some pretty strange noises before. Furballs never sound like fun!

But has your cat ever made a sound quite as bizarre as this?

According to his owner, this kitty in Tokyo, Japan makes this sound "when he's cranky".

So why's he got such a cattitude? Owner Tomohiro Ito says it's all because he spoke to the cat in a low voice.

"The Merry Christmas magpie, 'bleeping' parrot and 'loliloli' cat" (BBC, 2018)

(online) <https://www.bbc.co.uk/newsround/46259473>, 01/01/2017.

This humorous playful blend between cat and attitude is appropriate as it is aimed at presenting a funny video featuring a cat.

\subsubsection{Commercial attractiveness}

7 The process under study is also used for a commercial purpose, mainly when two motivations are combined: word play and melioration. Indeed, these motivations may both contribute to making a referent more attractive in a specific communicative situation. The adverb automagically, (automatically + magically) is used "esp[ecially] in the language of advertising" (OED Online 2018, s.v. "automagically, adv." ). The following utterance praises the convenience of using the commercial product that is presented here, explaining that Windows partitions are automatically resized in such an ingenious way that it seems magical. This blend is suggestive of a strategy in the commercial areas of marketing and communication. Not only is it motivated by melioration, but it is also - as a playful blend - aimed at drawing the reader's attention to the emphasized salient form in order to sell the product more easily.

(4) Xandros 4 installed fine. Xandros 4's installation routine is easy, and requires little to no knowledge of partitioning - provided you do not choose the 'advanced' method. It can automagically resize Windows partitions to make way for Xandros;

Holwerda Thom, "Review: Xandros Desktop 4.0" (OSnews Inc., 2006) (online) <https://www.osnews.com/story/16082/review-xandros-desktop-40/>, 05/01/2019.

As evidenced by the utterance below, a race car track Disneyland attraction is called autopia (automobile + utopia) (Bertinetto 2001 : 27 ; Cannon 1986 : 734), with the common <to> morphological segment between the two bases. This playful name catches the hearer's attention, which makes a commercially-aimed blend to name this leisure product.

(5) Autopia is the only existing Tomorrowland attraction dating back to Disneyland Park's opening day in 1955. When the cars first took to the road, they captured America's fascination with the latest transportation innovation, the "freeway."

Over the years, the roadways and car styles have been updated, but the fun stays the same.

“Autopia” (Disney, 2019) (online) <https://disneyland.disney.go.com/attractions/ disneyland/autopia/>, 22/05/2019.

\subsubsection{Literary aestheticism}

Aestheticism is sometimes what a blend is aimed at, especially in literary creations such as Shakespeare's rebuse (rebuke + abuse) (Cannon 1986 : 737):

(6) Petruchio. Verona, for a while I take my leave,

To see my friends in Padua; but of all 
My best beloved and approved friend,

Hortensio; and I trow this is his house.

Here, sirrah Grumio, knock, I say.

Grumio. Knock, sir! Whom should I knock?

Is there any man has rebus'd your worship?

Petruchio. Villain, I say, knock me here soundly.

Grumio. Knock you here, sir? Why, sir, what am I, sir, that I

should knock you here, sir?

Petruchio. Villain, I say, knock me at this gate,

And rap me well, or I'll knock your knave's pate.

The Taming of the Shrew, Act I, scene 2 (online) <https://

www.opensourceshakespeare.org>, 03/01/2019.

The character of Grumio uses a blend here probably because the playwright provides his lines with a literary, aesthetic and perhaps almost pompous style in order to create a comic effect because Grumio is confused, as he believes that Petruchio asks him to knock him, although his interlocutor rather asks him to knock on the gate beside them. Base words related by assonance and rhyme may create aesthetic blends (Bolinger 1950 : 130 ; Cannon 2000 : 953). Alliterations may also pepper blends in literature. A particular sort of blend are puns, when a double meaning is intended for at least one source word, and below, a Shakespearian phonological pun on the word sun - to be understood as sun or son - is enlivened with an alliterative /s/ sound in the following lines:

(7) Now is the winter of our discontent

Made glorious summer by this sun of York;

Richard III, Act I, scene 1 (online) <https://www.opensourceshakespeare.org>,

03/01/2019.

31 It turns out that aesthetic blending - together with acronyming and clipping (Bauer 1983 : 293-294) - is often a matter of euphony, since many literary examples stem from poetry or theatre, both of which are aimed at being spoken. In these situations, blends are intended to bring about pleasant sounds.

\subsubsection{Witticism}

\subsubsection{Witticism to defend one's ideas}

Algeo exposes scientific witticisms (1977: 61), for example with appestat formed with the noun appetite and the terminal combining form -stat bringing about the idea of a regulation (OED Online 2018, s.v. "appestat, n.", “-stat, comb. form1"). It is not perceived as a blend but a compound by the OED since the form stat acquired the status of morpheme, but stat is a splinter and appestat a blend "according to Webster's Third" (Algeo $1977: 61$ ). However, such scientific blends are created to satisfy the need to refer to a new extralinguistic element, and witticisms are placed here within the category of word play, thus requiring a linguistic link between the source items. A few examples "with a coy tone" provided by the same author (Algeo $1977: 60$ ) are constitutive of playful blends with a sarcastic goal. Californication (California + fornication) (Algeo 1977 : 60 ; Mattiello $2013: 305$ ) is notoriously used for the title of a song by the American rock band Red Hot Chili Peppers. A critical tone transpires in the song describing decadent aspects of Hollywood, such as pornography with the oxymoronic phrase "hardcore soft porn", or the resort to plastic surgery with the sentence "pay your surgeon very well to break the spell of aging". Therefore, the utterances of Californication, playing with the 
similar sounding of California and fornication, are sarcastic in this song and related to the end of a civilization:

(8) It's the edge of the world and all of western civilization

The sun may rise in the East at least it's settled in a final location

It's understood that Hollywood sells Californication

Pay your surgeon very well to break the spell of aging

Celebrity skin is this your chin or is that war you're waging?

Firstborn unicorn

Hardcore soft porn

Dream of Californication

Kiedis Anthony, Balzary Michael, Frusciante John Anthony, Smith Chad,

Californication (Universal Music Publishing Group, 2000).

The blend Cocacolinization (Coca-Cola + colonization) (Algeo 1977:60; Bertinetto $2001: 27$

; Mattiello $2013: 305)$ is based on the similarity between the first two syllables of the term colonization and the second part of the name of the company. The utterance below sarcastically denounces the cultural imperialism of the company enjoying a worldwide success, establishing a connection between the company, colonialism and alienation from one's culture of origin:

(9) What perhaps needs to be pinpointed is the Coca-Colanisation of post-colonial African youth who have not only been disconnected but alienated from their cultural moorings.

Memela Sandile, "The Coca-Colonisation of African culture" (This Is Africa, 2014) (online) <https://thisisafrica.me/lifestyle/the-coca-colonisation-of-africanculture/>, 03/01/2019.

In addition to a sarcastic aspect, witty blends are noticeable when the speaker or writer intends to defend an idea, either a political or humanitarian cause, or a more personal idea. The following blend pollutician (pollute + politician) (Algeo 1977 : 52 ; Mattiello 2013 : 308) shows that witty blends may be sarcastic and potentially expressing political ideas, here about the urge of political action for an ecological transition against pollution.

(10) So, all you D.C. polluticians, why wait for all that snow to melt?

DeMelle Brendan, "PolluterHarmony: A Match Made In Washington" (DeSmogBlog,

2010) (online) <https://www.desmogblog.com/polluterharmony-match-madewashington>, 03/01/2019.

Even if word play is limited to the overlapping /eks/ phonological segment in the base items of sexploitation (sex + exploitation) (Bryant 1974:181; Cannon 2000 : 952 ; Mattiello $2013: 309$ ), or /ks/ in blaxploitation (blacks + exploitation) (Bertinetto 2001 : 27 ; Cannon 2000 : 955 ; Mattiello $2013: 304$ ), there is a similarity between the etyma, although word play is low in these examples. These words may be employed to denounce different sorts of exploitation of people.

(11) Independent studios as well as the major studios began to target youth audiences with low budget films and different varieties of exploitation films, such as blaxploitation and sexploitation. These two genres are exactly what they sound like: films that exploit particular groups such as black culture or women (respectively).

Gray Gordon, Cinema: A Visual Anthropology (Berg, 2010) (online) < https:// books.google.fr/books?id=KZj75aW51EIC\&pg=PT36>, 03/01/2019.

The derived verb sexploit or noun sexploiter have the same effect:

(12) Governance analyst, Farai Mutondoro, concurs that women in rural, urban and peri-urban areas in Zimbabwe are 'sexploited' for land by local authorities and land 
officers.

Sauti Lazarus, "Women 'Sexploited' For Land In Zim" (263Chat, 2018) (online) $<$ https://263chat.com/women-sexploited-for-land-in-zim/>, 03/01/2019.

(13) But there are other real sexploiters who prey on minors and deserve the full punishment that the law metes out to them.

Robinson Tony, "Sexploitation" (Jamaica Observer Limited, 2015) (online) <http://

www.jamaicaobserver.com/columns/Sexploitation_19222656>, 03/01/2019.

\section{it merges morphologically and semantically similar source items, and it is sometimes} used to express personal points of view:

(14) Wendy Williams is \#torrible on this dance floor!!!!! Thats all

Johnson Tania L. (Twitter, 2011) (online) <https://twitter.com/mstaniaj/status/

$52544716725686272>, 03 / 01 / 2019$.

\subsubsection{Witticism with an Xphemistic (euphemistic or dysphemistic) purpose}

\subsection{Euphemism}

Witticisms with a euphemistic or dysphemistic purpose are also found in some contexts. The two following examples are related to the notion of taboo as sexuality and morality are culturally taboo semantic subjects (Holder $1995: 415$; Tournier 1985 : 272, 273 ; Tournier $2004: 155-157$ ), and taboo is related to euphemism (Crystal 1995 : 172). The common <ex> segment between the source words sex and ambidextrous (Algeo 1977 : 52 ; Bryant 1974 : 180 ; Mattiello 2013 : 303) motivates the playful blend ambisextrous that may serve as a euphemistic blend for "bisexual", as in the following utterance.

(15) The witty and very mischievous stage and screen actress didn't describe herself as bisexual. "Ambisextrous" was the term she preferred.

Macnab Geoffrey, "Homophobia in Hollywood: Why gay movie stars still can't come out of the closet" (TheIndyFilm, 2013) (online) <https://www.independent.co.uk/ arts-entertainment/films/features/homophobia-in-hollywood-why-gay-moviestars-still-cant-come-out-of-the-closet-8455751.html>, 04/01/2019.

The euphemism is blatant in this situation about a bisexual woman who prefers the blended form, in an article about homophobia in Hollywood. The same holds true in certain contexts for the pun sinema graphically indicated by the letter $<\mathrm{s}>$ instead of the $<\mathrm{c}>$ of cinema, so as to include the term sin entirely overlapping with the first syllable of cinema phonologically. This moralizing word associated to cinema discreetly designates adult films (Algeo $1977: 49$; Mattiello $2013: 309$ ), and is employed euphemistically in the utterance below:

(16) The movie is part of the Super Secret Saturday Night Sinema series, which takes place on the last weekend of each month.

(...)

"It's not porn," assures Lee Demarbre, programmer for the Mayfair. "It's a masterpiece of erotic cinema directed by the Alfred Hitchcock of the genre that was shot in British Columbia."

Bustos Alejandro, “"Top Secret” lost erotic masterpiece to screen at the Mayfair" (Apt613, 2013) (online) <https://apt613.ca/lost-hitchcock-erotic-masterpiece-toscreen-at-the-mayfair/>, 04/01/2019.

An example of a three-constituent blend which is prone to be euphemistic is the form basticherbator mixing three rude words (bastard + bitch + masturbator) (Beliaeva $2014: 7$ ) into one lexical unit making these words less shocking: even if the constituents are 
insulting, the substitutive blend sooths the effect of these base elements, thus providing the substitution with a euphemistic function. It is used disparagingly to refer to an annoying person, although no utterance is found in Google apart from Kemmer's example sentence "Stop being such a basticherbator!" (Kemmer 2008).

\subsection{Dysphemism}

original. Locutors perform idiosyncratic playful blends (Bauer, Lieber, Plag 2013 : 485 ; Bertinetto $2001: 5$ ) in order to prove their creativity and originality. A long-lasting adoption of these coinages is not intended, and nonce words are ideal for this end. As Cannon explains, there are "people who are enjoyably indulging their linguistic individuality, in a kind of dynamic, impermanent word formation" (Cannon 1986 : 750). A few examples are Internot (Internet + not) referring to someone who refuses to use the Internet, or transwestite (west + transvestite) to denote someone who likes dressing up as a cowboy (Bauer, Lieber, Plag 2013 : 485). Both of these examples play with a morphological similarity between the base items. A blended form coined for a special occasion appears in the series Atypical, when the protagonist's sister claims that what her autistic brother wants her to drink as a ritual for her birthday is ritualicious, which plays on the letter <l> shared by the two source words ritual and delicious so as to create 
an original form which applies exclusively to the interlocutors' situation. The nonce (or at least very occasional) form underlines the hero's ritualistic behaviour and the uniqueness as well as the oddity of her brother's requirement.

(19) Sam: Wait, you need to drink your birthday chocolate milk.

Casey: Sam, I can't drink this. It's like it's looking at me.

Sam: But it's part of the ritual!

Casey: Mmm, ritualicious!

RASHID Robia (Dir.), 2017, Atypical (online), Exhibit A ; Sony Pictures Television,

season 2, episode 9.

The character of Humpty Dumpty forcefully praises creativity and originality by reciting a poem with novel forms, especially through the then unattested playful blend slithy (lithe + slimy):

(20) 'Twas brillig, and the slithy toves

Did gyre and gimble in the wabe;

All mimsy were the borogoves,

And the mome raths outgrabe.

'That's enough to begin with,' Humpty Dumpty interrupted: 'there are plenty of

hard words there. "Brillig" means four o'clock in the afternoon-the time when you

begin broiling things for dinner.'

'That'll do very well,' said Alice: 'and "slithy"?'

'Well, "slithy" means "lithe and slimy."

CARROLL Lewis, Through the Looking-glass (online) < https://www.gutenberg.org/

files/12/12-h/12-h.htm>, 04/01/2019.

Humpty Dumpty explicitly claims that such a poem is intended to be innovative since anyone can repeat something, but creating an original poem is much harder and more interesting. He even criticizes the lack of creativity in many people, which justifies his goal to promote novel word crafting.

'As to poetry, you know,' said Humpty Dumpty, stretching out one of his great hands, 'I can repeat poetry as well as other folk, if it comes to that-'

(...)

Humpty Dumpty replied in a discontented tone, giving her one of his fingers to shake; 'you're so exactly like other people.'

Carroll Lewis, Through the Looking-glass (online) <https://www.gutenberg.org/files/ 12/12-h/12-h.htm>, 04/01/2019.

The purpose of playful blends is to change the focus on a reference in the discourse so as to emphasize or diminish what is referred to. This goal is mainly emphatic, with various intentions such as humour, commercial attractiveness, witticisms to express one's political or personal ideas, literary aestheticism to embellish a discourse and impress the audience, dysphemism to shock one's interlocutors, or idiosyncrasy to manifest one's individuality or appear as original and creative. More discretion is searched only with the help of euphemistic playful blends whose heightened concision (based on their overlapping source words) and reduced transparency decrease the impact of unpleasant forms. Still, in both cases, cognitive salience is at its height for playful blends, as the attention of the interlocutors is drawn towards a novel or nonce word, subtly and uncommonly coined by playful blending which requires to recognize the clipped source items and realize the particular linguistic link between them. This constitutes the motivation of playful blends.

The playfulness of specific forms has been described as a motivation for blending, and it has been revealed that the purpose of playfully motivated blending is to obtain a higher cognitive salience in the discourse. A number of purposes to blend words have 
also been provided and developed separately. However, a form does not necessarily correspond to one motivation, and an utterance is not systematically driven by a unique purpose: the motivations and purposes lying under a blend are often manifold. The above taxonomic approach has artificially clarified the impetus of playfully blending words, but one should bear in mind that blending in a specific situation is frequently not a one-factor phenomenon, being a combination of several elements.

\section{The multiplicity of the motivations and purposes in playful blending}

49 The motivations and purposes of playful blending are often combinative: other motivations than word play, and different purposes inherent to a higher cognitive salience may co-exist in playful blends.

\subsection{Multi-motivated playful blends}

Blends which are primarily motivated by something else than word play may be playful to a certain extent, as long as the source words are at least partially related linguistically. The use of attested words for "conscious creations" enables speakers to fill "a semantic void in the lexicon" (Cannon 2000 : 953). They are "serious coinings, often naming man-made objects, processes, and facilities" (Cannon $1986: 746)$, that are consequently needed to communicate more efficiently referring to newly created extralinguistic elements. They are composed of pre-existing words for the sake of being transparent, as these base words themselves tend to define the output form. Moreover, they are linguistically linked, so that the blends are motivated by playfulness, in addition to transparency. The use of blending for the name of the company Groupon (group + coupon) (Eldridge 2011) is motivated by the explanatory function of the source words, as the enterprise "groups" together local merchants and subscribers who collect money-off vouchers or "coupons", but this motivation is doubled with word play, as the two source items have the vowel sound / $\mathrm{u}$ / in common.

Blending is a denser way of speaking or writing, which "save(s) time and paper in communicating" (Devereux $1984: 210$ ), according to the principle of "least effort" and "cognitive economy" (Mattiello $2013: 27$; Tournier $2004: 162,195$ ), also referred to as "linguistic economy" (Tournier $2004:$ 161-162) regarding the process of clipping inherent to blending. Fusing two or more words together enables interlocutors to reduce the number of phonemes to pronounce, or letters to write. Blending can be motivated by an easier written or spoken performance with the help of concision, or “communicative economy" (Grzega, Schöner $2007: 36$; Miller $2014: 84$ ). While a classic composition is often chosen to refer to bi-national or bi-cultural people, as in AfricanAmerican, the form Amerindian (American + Indian) (Mattiello $2013: 303$ ) is coined to designate an American-Indian more concisely, but it also playfully uses the similarity between the two source forms, as they share the same suffix -an and the phoneme /I/. In comparison, the competing adjective and noun Amerind (Algeo $1977: 56$; Mattiello 2013 : 303) is more concise than playful.

52 Another motivation which may appear in combination with playful blends is melioration. The first word of Extell Development Company is derived from two highly meliorative words (excellence + intelligence) (Extell.com 2018), thus praising the company 
with two qualities, in addition to word play based on the common form <ell>. Two marketing arguments are made within the very name of the enterprise, which motivates the blend with melioration. The American online travel agency Travelocity.com uses this strategy too, with a blend word indicative of velocity, while transparently denoting the type of enterprise with the term travel (Kemmer 2008), and playfully exploiting shared segment $<$ vel $>$ in the base elements travel and velocity. This example illustrates the use of blending with a threefold motivation, so as to name a new company in a playful, transparent and meliorative way.

\subsection{Multi-purpose word play in blends}

Blends may combine different purposes within word play. The dysphemistic purpose of playful blends that was illustrated previously displays utterances showing that a second purpose is likely to be combined with dysphemistic playful blends: they tend to be humorous too. Craptacular (crap + spectacular) (Mattiello 2013 : 305 ; Oxford Dictionaries, s.v. "craptacular") is a playful adjective as the two source words have a special semantic link: they create an oxymoronic effect. The utterance below of craptacular is aimed at being both dysphemistic for a word expressing a very strong badness which may be paraphrased by "spectacularly crappy", and humorous for an oxymoronic word in a discourse full of irony, where the author pretends that it would be a good thing if Taiwan had such bad films like other prominent movie companies elsewhere in the world.

(21) Far be it from anyone to suggest that Taiwan doesn't deserve its craptacular action movies just like every other cinematically developed nation, but the industry can and surely will do better in the future, especially if it hires a director who knows how to do something with a scene other than chopping it up or packing it with explosives.

Chang Justin, "Busan Film Review: 'Black \& White: The Dawn of Justice"' (Variety Media, LLC, 2019) (online) <https://variety.com/2014/film/festivals/busan-filmreview-black-white-the-dawn-of-justice-1201323240/>, 04/01/2019.

In the following utterance, a comic short film featuring a hairdresser's misadventures is entitled "Hairrible Sunday". The use of the blend hairrible (hairy + horrible) - playing with the common /rI/ phonological segment between the source words - is aimed at providing the title with humour and making it stand out, for advertising purposes. Here, not only does blending makes the title humorous, but it also catches possible viewers' attention.

(22) Hairrible Sunday ANIMATION SHORT FILM

"Hairrible Sunday ANIMATION SHORT FILM" (Bumpkin Production, 2016) (online)

<https://www.youtube.com/watch?v=pXiiH9zaxe4>, 22/05/2019.

Multiple motivations and purposes in the same utterance demonstrate that purpose as well as motivation are not context-free. A form is not related to precisely the same combination of motivation(s) and purpose(s) from one situation to another, so that pragmatics is at stake in the purposes and motivations of a playful blend. As these two notions are context-dependent, their relation to context should now be examined. 


\section{Motivation's and purpose's relation to context} related to context, in order to demonstrate the distinction between these two concepts. To this end, two methods will be used. Firstly, utterances of the same playful blends in various situations will be studied. Secondly, coreferential forms inside and outside playful blending will be examined in different contexts.

\subsection{Purpose is utterance-based}

ination of various utterances of the same playful blend in different situations is fruitful in revealing how the motivation and purpose of a single form relates to individual contexts. The writer of the text of this celebrity website manifestly intends to make the discourse pleasant to read, hence the jocular tone of the introductory lines below:

(23) Hello my fellow celesbian trackers! There's been a drought in hot celesbian news. The last gift we got was that Barb from Stranger Things came out as bisexual, but that was in APRIL. It's now basically September and the leaves are gonna start falling like, tomorrow. So I figured that we all need to just look at these pics of Stella Maxwell and Kristen Stewart to feed our hungry little celesbian news souls. Yapalater Lauren, "Quite Literally Just A Few Pics Of Kristen Stewart And Stella Maxwell To Feed Your Celesbian Need" (BuzzFeed, 2017) (online) <https:// www.buzzfeed.com/lyapalater/quite-literally-just-a-few-pics-of-kristen-stewartand $>$, 05/01/2019.

The repeated use of celesbian (celebrity + lesbian) (Bauer, Lieber, Plag 2013 : 484) contributes to a humorous tone, playing on the comical aspect of curious readers with the phrases "my fellow celesbian trackers" and "feed our hungry little celesbian news souls", explaining that there are new pieces of information to deliver in a funny metaphorical way through the clause " $(t)$ here's been a drought in hot celesbian news", and humorously expressing the hyperbole that looking at pictures of lesbian celebrities are necessary for everyone: "we all need to just look at these pics".

By sharp contrast with the previous utterance, celesbian in the following context is used seriously in this analytical book about mainstream popular music. The concision of the playful blend is understandable in its way of intellectualising the discourse, together with a few co-utterances: the interrelated concepts of lesbianism and celesbianism. This witticism contributes to an analytical and intellectualising tone.

(24) Articles in the lesbian and gay press have shown great disdain towards the emergence of Katy Perry-style celesbianism within mainsteam pop. In an article titled 'Lesbianism: The New Black', Duggan (2008a) slams the celesbian craze, saying that 'with Madonna too busy working on her new face to spend time culturally raping minorities any more, it's up to the new breed of singers like Katy Perry to take what they can from the lesbian scene and milk it for all it's worth before its value runs out'.

Baker Sarah, Bennett Andy, Taylor Jodie, Redefining Mainstream Popular Music (Routledge, 2013), p.47 (online) <https://books.google.fr/books?id=zcMuMglzyzkC>, 05/01/2019.

While both of these utterances of celesbian are motivated by the will to play on the common segments of their etyma $<\mathrm{le}>$ and $\langle b>$, the purposes of the writer are different from one context to another, thus demonstrating that a particular form is linked to 
motivation, regardless of the contexts of use, but the purpose of a same form changes from one context to another.

61 Another example may be displayed with the blended word infotainment (information + entertainment) (Bauer, Lieber, Plag $2013: 459,461$; Mattiello $2013: 307$ ), whose use is driven by different reasons in the following utterances.

(25) Plenty of online connectivity through infotainment apps - the head unit comes with a Raku digital radio app as standard, and this supports most local radio stations which offer broadcasts digitally.

LIM, Anthony, "Proton X70 GKUI Android-based infotainment system detailed music streaming, live traffic GPS navigation" (Driven Communications Sdn Bhd, 2019) (online) <https://paultan.org/2018/10/11/proton-x70-gkui-android-basedinfotainment-system-detailed-music-streaming-live-traffic-gps-navigation/>, 22/05/2019.

62 A commercial aim prompted the blend, as it is part of the presentation of a phone, praising the advantages of the product.

(26) Steer your internet browser towards infotainment websites so you can waste time while actually learning very very very interesting things.

"6 websites your boss doesn't mind you wasting time on" (Careers24, 2019) (online)

<https://careeradvice.careers24.com/career-advice/work-life/6-websites-your-

boss-dont-mind-you-wasting-time-on-20160617>, 22/05/2019.

The above utterance stands in sharp contrast with the previous one. The approach is not commercial but rather ironic and humorous. The writer is ironical about the futility of people's habits to visit entertaining websites, stating that the information that they convey is "very very very interesting", and that it enables us to "waste time". Related to unique contexts, purpose is empirical, which is not the case for motivation. Purpose is dependent on single contexts, on the contrary to motivation. The purposes vary for each individual situation.

\subsection{Motivation is usage-based}

Notwithstanding motivation's independence to single contexts, it is connected to collective contexts. Competing synonymous forms can be explored in various contexts so as to show how motivation and context are interdependent despite its independence from the singularity of a situation. If the forms American Indian, Amerind and Amerindian as a noun or as an adjective all have the same referent (designating American Indians), they are employed in different sorts of contexts because of their multiple motivations whose order of importance and/or nature changes from one form to another. They share the same definition, but there is a diatechnic variation (Hausmann 1977 : chap.8, 1989 : §4) among them due to the more scientific connotation of Amerind. The unclipped compound American Indian is a form exclusively motivated by the purpose to be transparent. The playful blend Amerindian is prominently transparent and concise and secondarily playful. The more shortened playful blend Amerind is mainly motivated by concision, and secondarily transparent and playful. Accordingly, Amerind is scientifically connoted as it "orig(inally) and chiefly" appears in "cultural anthropology", whereas American Indian and Amerindian are more commonplace, described as simply referring to "the indigenous peoples of the Americas" (OED Online 2018, s.v. "American Indian, n. and adj." "Amerindian, adj. and n.", "Amerind, n. and adj."). The utterances provided in the two corpus-based articles of the dictionary are also meaningful, since they are mainly of scientific order for Amerind, and from more 
various sources for American Indian and Amerindian. These two different contextual uses may be due to the prominence of transparency for the forms American Indian and Amerindian, which enables them to appear in scientific as well as non-scientific discourse. While transparent forms are largely used in various contexts, including scientific ones, the highly concise form Amerind appears chiefly in scientific contexts. Concision lends itself better to formal scientific discourse as interlocutors repeatedly refer to this group of people. Even if interlocutors who are not initiated to cultural anthropology understand the word Amerind, a more transparent form is preferred for non-scientific use.

65 Tiger-lion hybrids prompted the use of various blends. Liger have a slightly different meaning than tigon, tiglon and tigron, as it is a cross between a lion and a tigress, whereas tigon, tiglon and tigron refer to the offspring of a male tiger and a female lion (OED Online 2018, s.v. "tigon, n.", "liger, n."). The coreferential blends tigon, tiglon and tigron are supposedly playful, in that their coinage may have been motivated by the common letter $<i>$ and phoneme /aI/ of their two source words. An examination of the frequency of occurrence of these three synonymous forms shows that after tiglon's overwheming preference in the 1940s, tigon is preferred to tigron and tiglon from the second half of the twentieth century onwards, which displays diachronic and diafrequential variations (Hausmann 1977 : chap.8, 1989 : \$4) among these competing forms (Google Books Ngram Viewer 2013). In the scientific domain, the number of results of tigon (1,600), tigron (164), tiglon (236), tigons (193), tigrons (201) and tiglons (45) (Google Scholar 2019) does not provide another possible conclusion than a preferred use of the form tigon, without a diatechnic variation which could have been suspected, with a possibly more scientific connotation of one form.

66 A huge frequency variation is noticeable between the different synonymous forms hacktivist (hack + activist) (OED Online 2018, s.v. "hacktivist, n. and adj."), hactivist (hack + activist) (OED Online 2018, s.v. "hacktivist, $n$. and adj.") and hackervist (hacker + activist) (Bassac 2012 : 186). The word hackervist is extremely marginal with 39 results in Google Books (2019), compared to its synonyms hacktivist with 68,900 results in Google Books (2019) and hactivist (hack + activist) (OED Online 2018, s.v. "hacktivist, n. and adj.") with 3,590 results in Google Books (2019). The more similar to the source words the blend is, the more popular it is for these words: it may be hypothesized that the playfulness of the blend is favoured.

Not only does variation categories such as frequency or domain come into play among synonymous blends, but it seems that the degree of emphasis expressed varies among them. The playful blend fantabulous (fantastic + fabulous) (Arndt-Lappe ; Bassac 2012:190 ; Plag 2012 : 2 ; Bertinetto 2001:27 ; Mattiello 2013:306) has a counterpart with an inverted order in the base words: fabtaslic (fabulous + fantastic) (Bauer, Lieber, Plag 2013 : 459). Even if fabtastic is sometimes defined in the same way as fantabulous (fantastic and fabulous) (Collins Dictionary 2019, s.v. "Fabtastic"), according to the Urban Dictionary (2019, s.v. "Fabtastic"), fabtastic is more than fantastic or fabulous, but not good enough to be described as fantabulous (Urban Dictionary 2019, s.v. "Fabtastic"), supposedly because fabtastic is formed with the adjective fantastic, to which the letter $<\mathrm{n}>$ is merely replaced with $\langle b\rangle$, whereas fantabulous is formed with the adjective fabulous, to which is added the segment $<$ nta $>$. As it may be cognitively perceived, the replacement of a mere letter in fabtastic is weaker than the addition of three letters in fantabulous. Thus, the meaning of the playful blend motivationally transpires in its morphology, with more or 
less morphological material that is gained in the output. In this way, the very forms of the playful blends fantabulous and fabtastic are suggestive of the degree of wonder in their meanings. There is also a sharp diafrequential variation (Hausmann 1977 : chap.8, 1989 : \$4) between the two blended forms: fantabulous has 11,700 results and fabtastic only 1,650 in Google Books (2019).

The number of synonymous blended forms for the two source words positively and absolutely recorded in the literature is outstandingly high, as seven forms of playful blends have been noticed. Both of the source words are emphatic, forming significantly emphatic blends accordingly. It is worth noticing that the seven recorded blends may be divided up into two parts, depending on the order of the two source words. Positively as the initial base delivers posilutely (Mattiello $2013: 309$ ), posolutely (Oxford Dictionaries 2019, s.v. "posilutely") and postolutely (Oxford Dictionaries 2019, s.v. "posilutely"), and absolutely as the first component provides absolively (Mattiello 2013 : 309), absotively (Bassac 2012 : 190 ; Mattiello 2013 : 303), absatively (Oxford Dictionaries 2019, s.v. "absotively") and absitively (Oxford Dictionaries 2019, s.v. "absotively"). This twofold division is relevant as two blended forms are often paired in the same context, one taking positively as the initial source word, the other form taking absolutely as the first source term (OED Online 2019, s.v. "posilutely, adv.", "absotively, adv."), in order to intensify the emphasis. Thus, the degree of emphasis is heightened with the use of a second blended form by inverting the order of the components. Using only one form is different than employing two forms together: it enables interlocutors to express different degrees of emphasis, according to how the situation is perceived by them. The mechanism is to provide several degrees of emphasis, gradually: firstly with just one unblended form which can be paraphrased by "(e)mphatically" (OED Online 2019, s.v. "posilutely, adv.", "absotively, adv."), secondly more intensely with a form playfully blending two emphatic source words, and thirdly with a significant force and insistence through two of these playful blends employed consecutively. As illustrated below, a free indirect speech displaying many exclamations and interrogations, and using exclamatory capital letters, is compatible with an extremely emphatic discourse employing two of these forms of playful blends:

(27) Some kinds of people might tend to like certain comics better than others, but there aren't actually any rules about who can like what comics. There's definitely not a rule that says certain people can't like comics at all!

You've probably been told that comics are a boy thing. You might even have been told that comics aren't for you, that people like you-whatever flavor of person that is-just don't like comics. Well, I'm here to tell you that they're absotively, posilutely, one-hundred-percent WRONG.

Can you imagine never getting to try pizza because somebody said that only blond people liked pizza? Or never riding a bike because you heard there were no bikes for people who were left-handed?

West Jordan, "Comics 201, Special Edition: A Kids' Guide to Talking Comics" (The Mary Sue, 2015) (online) <https://www.themarysue.com/comics-201-specialedition-a-kids-guide-to-talking-comics/>, 05/01/2019.

Other utterances using only one of these blends are emphatic to a lesser degree:

(28) - In truth, Dr O'Reilly, I'd say there's been nothing that's absotively a surprise to me.

Barry Kevin, "Kevin Barry short story: Roethke In The Bughouse" (The Irish Times, 2015) (online) <https://www.irishtimes.com/culture/books/kevin-barry-shortstory-roethke-in-the-bughouse-1.2308905>, 05/01/2019. 
The communicative situation influences the use of one form (or a combination of more than one form) among competing coreferential forms. This is the reason why a form lends itself more or less well to a specific context, compared to its synonymous counterparts. Therefore, even though motivation is not dependent on single contexts as previously developed, it is not context-free either, being dependent on particular sorts of contexts. Motivation makes it possible to define categories of collective contexts. Motivation is usage-based, whereas purpose is utterance-based.

71 As discussed previously, in order to identify the motivation of a blend, one has to rely on the recursive uses of a form in many different contexts (which is the work of semantics), and that purpose unveils itself in a single specific context (which is the task of pragmatics). Furthermore, a particular combination of motivations and purposes in an uttered playful blend fully depends on a single communicative situation, so that motivation is situated on a semantic-pragmatic level, and purpose is fundamentally pragmatic. In addition, a playful blend taken outside any context may be ambiguous regarding its meaning or etyma, which makes pragmatics essential to the formation under study, as will be developed below.

\section{The disambiguation of equivocal playful blends}

It occurs that some blends are equivocal and present more than one possible interpretation, depending on the semantic relation between the input constituents, the number of source words, or the source words themselves in the case of homonymic playful blends. The motivation of a playful blend sometimes reveals itself when the word is uttered in a communicative situation. While sexyllent is univocal and necessarily means "sexy and excellent", sexcellent may be taken coordinately as "sexy and excellent", or reinterpreted in an attributive way as "excellent in sex" if the input words are sex and excellent (Mattiello 2014 : 137). The following utterances of sexcellent disambiguate the blend thanks to the nature of the referent on which the blended adjective applies, sexcellent in the sense of "excellent in sex" describing a human referent (in (29)), in contrast with sexcellent when it means "sexy and excellent" (applying to a song in (30)):

\section{(29) Be SEXcellent}

A guide on how to have excellent sex - for students, by students. Whether you're active now or plan to be in the future, this guide can help you excel at safer, more satisfying sex.

"Be Sexcellent" (Regents of the University of California, 2019) (online) <https:// well.ucr.edu/programs/health-education/be-sexcellent>, 14/01/2019.

(30) I think it's a sexcellent song that would fit comfortably on Abbey Road, and part of one of the weirdest and most adorable urban legends in rock history.

"vordhosbn", 2005, in "Klaatu- Calling Occupants of Interplanetary Craft" (Ziff Davis, LLC, 1996-2019) (online) <https://www.ign.com/boards/threads/klaatucalling-occupants-of-interplanetary-craft.78444381/>, 14/01/2019.

The playful form Blacktivist (black + activist) (Bassac $2012: 186,189$ ) is "ambiguous and refer(s) either to a black person who promotes a cause that is not specified, or a person who promotes the cause of black people" (or both). The utterances below demonstrate that according to the context, this blend may refer to a black activist (31), an activist fighting for black people's rights (33), or both (32). This utterance of blacktivist (in (31)) designates a black activist woman who fights for the rights of black people, as the 
character of American rapper Tupac Shakur's mother is Afeni Shakur, who joined the Black Panther Party.

(31) The film tries to shoehorn a social issue with Tupac's mother being a blacktivist, and the internal conflict that Tupac has with whether to stand up for his community, but that too is weakly executed.

FADNAVIS Mihir, 2017, "All Eyez on Me movie review: This 2pac biopic is a compilation of videos with very little story", Firstpost (online) <https:// www.firstpost.com/entertainment/priya-prakash-varrier-posts-pictures-withranveer-singh-vicky-kaushal-will-she-be-seen-in-karan-joharstakht-5892861.html>, 14/01/2019.

74 This context is about a young black woman who developed her skills and visibility to fight for social causes inside and outside the rights of black people, for example on gentrification, thanks to the Youth Action Team.

(32) She said they helped her develop her skills and voice as an artist and a leader. She described herself as a "blacktivist" who performs spoken-word pieces on topics like gentrification and the Black Lives Matter movement.

KADVANY Elena, WEEKLY Palo Alto, "Youth group to open community arts and music center in East Palo Alto" (online) <https://www.paloaltoonline.com/news/ 2016/01/15/youth-driven-movement-secures-land-to-open-community-arts-andmusic-center-in-east-palo-alto>, 14/01/2019.

The utterances below of blacktivist illustrates the use of the playful form to refer to any person struggling for black people's rights, regardless of his or her skin colour.

(33) We are all Blacktivist not by race or color but by strength and will to see a better future. To me a Blacktivist is someone who is selfless, colorless, and humble in the cause for which they fight for.

"Whitley Presents CH\&MP", 2015, "BLACKTIVIST - Champ", YouTube (online) <https://www.youtube.com/watch?v=SfKQEg2rlJY>, 14/01/2019. Carbage (car + garbage) (Bassac 2012 : 188 ; Bauer, Lieber, Plag $2013: 483$ ) may be paraphrased as "a piece of garbage turned into a car" if the blend is right-headed, as "a car that looks like garbage due to distasteful modifications" if the blend is left-headed, or as "the garbage that accumulates in a car" with an argument having a telic role (Bassac 2012 : 188). This third possible interpretation is also based on a left-headed analysis of the blend, which is problematic since it cannot be disambiguated in formal semantics' qualia structures. "( $\mathrm{T}$ )he role of semantics is only to provide potential senses, whose actualization belongs to the domain of pragmatics" (Bassac $2012: 188$ ). Bisquick is less enigmatic as its meaning varies diachronically, originally referring to "a baking product intended for making biscuits quicker", and now to "various baked goods" (Bassac 2012 : 189).

77 Regarding homonymic playful blends, the ambiguity stems from different interpretations of the base words. The aforementioned form carbage may also be a combination of carbohydrate and garbage (Collins English Dictionary 2019, s.v. "carbage"). Sometimes, the etyma are completely different: fleep may correspond to the combination of flying and jeep (Bertinetto $2001: 27$ ), fly and jeep (Bryant $1974: 175$ ) or fuck and sleep (Urban Dictionary 2019, s.v. "fleep"). The number of constituents may also vary in the interpretation process: while Thankshallowistmas "is definitely a three-part blend" (Thanksgiving + Halloween + Christmas) (Beliaeva $2014: 4$ ), the form on-call-ogist may be analysed as either a three or a two-constituent blend, from on + call + oncologist or from the adjective on-call and the noun oncologist, but in the following context, the interpretation clearly entails only two input forms (Beliaeva $2014: 4$ ): 
(34) She looked at me, her eyebrows twisted. "Yeah, I'm on call three times a week."

"Doesn't that mean you're an on-call-ogist?"

ORCHARD Jack, Extra Hands (Lulu.com, 2007), p.125.

78 The limits of a purely semantic approach are blatant in the case of ambiguous (playful) blends. The semantics of ambiguous forms is useful in listing potential meanings, sometimes informally if it is not expressible with structures but with paraphrases, but coupled with pragmatics, the utterances unveil their motivation, so that the concept of motivation straddles semantics and pragmatics.

\section{Conclusion}

Lexical blending may be motivated by the transparent formation (Cannon 2000 : 954) of a new lexeme to designate a new referent (Cannon 1986 : 746) in an explanatory or defining composition, a meliorative way of designating or describing a referent, the intention to be more concise for linguistic economy, and/or word play to increase cognitive salience by merging linguistically related source words. This linguistic link is recognized by the interlocutors and takes roots in a morphological and/or semantic similarity between the source words, or an oxymoronic relation between them (antonymic words are playful only if they are aimed at producing an oxymoron). The playfulness of some blends is occasionally remotivated afterwards, if interlocutors associate semantic traits to a consonant cluster of input forms contained in a preexisting blended form to coin other blends, thereby remotivating the original form with phonesthesia (Smith 2014). Thus, a bidirectional motivation may occur with phonesthetic playful blends.

The main purpose of playful blending is to produce a form which is particularly salient. The lexical unit is outstandingly concise, so that the audience has to recognize the source items of a novel or nonce form and realize the special linguistic relationship between its components, while the environing text of the playful blend is mostly composed of simplex forms, derivatives or at worst unclipped compounds. It changes the focus of the interlocutors towards an output form to emphasize or obscure it. The reference stands out from the environing text if the intention is humour, commercial attractiveness, witticisms to express one's political or personal ideas, literary aestheticism to embellish a discourse and impress the audience, dysphemism to shock one's interlocutors, or idiosyncrasy to manifest one's individuality or appear as original and creative. Conversely, it fades away if the blend euphemistically dissimulates the unpleasant input lexemes of a highly concise output form.

It follows therefrom that purpose and motivation have a cognitive dimension in playful blending. A word is playful only if it is employed as such. The opacification of a blend prevents the interlocutors from recognizing the constituents having a special relatedness. The link is cognitively made between the source words so as to create and understand the play on words. A blended form transpires in a communicative situation with an intensified cognitive salience: it stands out from the whole discourse, as it requires the special process of decoding two or more source words and the nature of their relationship within one lexical unit to unveil its meaning. The main purpose of playful blends is cognitive as it changes the way the interlocutor focuses on the lexeme that is rendered emphatic or less blunt. 

motivations (with traces of their pre-blending form) and purposes (with the possibly complex intentions of a speaker or writer) may co-exist in a blend. Multi-motivated and multi-purpose playful blends question the relation that motivation and purpose have with context. Two methods have been used to clarify the distinct relation that motivation and purpose have with context: the examination of the same playful blend in various contexts, and the analysis of the use of competing forms which are coreferential with a playful blend. It is evidenced that motivation is on the semanticpragmatic interface, whereas purpose is left to pragmatics, so that motivation may be described as usage-based, and purpose as utterance-based. Motivation is related to a form which has concurrent morphological versions varying the degree of cognitive salience and encompassing whole types of contexts in extralinguistic variation categories (such as diatechnic variation regarding specialized semantic areas, or diafrequential variation when different synonymous forms have distinct usage frequencies (Hausmann 1977 : chap.8, 1989 : §4)). Purpose is situated on a purely pragmatic level, as its interpretation is fully dependent on individual utterances. because a blend is no longer considered playful if it is read or heard as a simplex form. The semantic-pragmatic motivation of a form keeps semantics useful, but in the case of ambiguous blended forms, pragmatics has to take over semantics' limits to identify the referent. Another notable tie is established in this respect. Not only does cognition associate motivation and purpose, but motivation also links up semantics and pragmatics. As regards semantics, the meaning of a univocal blend is revealed by the non-arbitrary relationship between the input words (with one possible semantic structure), the very form of a blend discloses its motivation(s) and the playfulness of a blend hinges around the existence of a linguistic, sometimes semantic link between the components. As for pragmatics, the meaning of an equivocal blend is revealed by its utterance in a specific context, the aim of the locutor transpires in a particular communicative situation, the blended form is emphasized through a heightened cognitive salience due to the linguistic relatedness between the source elements, and when the form is multi-motivated, the context of utterance opens access to a hierarchical importance among the multiple motivations.

Semantic relatedness turns out to be on the forefront of the motivation to unite two or more source lexemes in an unexpected playful manner (even if the link is often morphological), and remotivation of playful blending through the rise of phonesthemes in later blends is rooted in the association of semantic traits to consonant clusters. Thus, a more in-depth analysis of the semantic ties between lexemes occurring through playful blending and phonesthemes may be conducted with the help of new statistical tools (Smith 2014 : 32-33), such as correspondence analysis (Glynn 2014) or vector space models analysing semantic density (Clark, Kaufmann, Sagi 2009 ; Turney, Pantel 2010). 


\section{BIBLIOGRAPHY}

ADAMS Valerie, 1973, An Introduction to modern English word formation, London: Longman.

ALGEO John, 1977, "Blends, a structural and systematic view”, American Speech, n52, 47-64.

ALLAN Keith, BURRIDGE Kate, 1991, Euphemism and Dysphemism: Language used as Shield and Weapon, New York; Oxford: Oxford University Press.

ARNDT-LAPPE Sabine, PLAG Ingo, 2012, "The role of prosodic structure in the formation of English blends", English Language and Linguistics, $n^{\circ}$ 17, 537-563.

BAESKOW Heike, 2004, Lexical Properties of Selected Non-native Morphemes of English, Tübingen: Gunter Narr Verlag.

BASSAC Christian, 2012, "A Combinatory Logic and formal-semantic account of lexical blending", in RENNER Vincent, MANIEZ François, ARNAUD Pierre Jean-Louis, 2012, Cross-Disciplinary Perspectives on Lexical Blending, Berlin; Boston: De Gruyter, 169-192.

BAT-EL Outi, 1996, "Selecting the Best of the Worst: the Grammar of Hebrew Blends", Phonology, $\mathrm{n}^{\circ} 13,283-328$.

BAUER Laurie, 1983, English Word-Formation, Cambridge: Cambridge University Press.

BAUER Laurie, 2004, A Glossary of Morphology, Edinburgh: Edinburgh University Press.

BAUER Laurie, 2006, “Compounds and minor word-formation types", in AARTS Bas, MCMAHON

April (Eds.), The handbook of English linguistics, Oxford: Blackwell: 483-506.

BAUER Laurie, LIEBER Rochelle, PLAG Ingo, 2013, The Oxford Reference Guide to English Morphology, Oxford: Oxford University Press.

BELIAEVA Natalia, 2014, "A study of English blends: From structure to meaning and back again", Word Structure, $\mathrm{n}^{\circ} 7,29-54$.

BERTINETTO Pier Marco, 2001, "Blends and syllable structure: A four-fold comparison", in LORENTE Mercè, ALTURO Núria, BOIX Emili, LLORET Maria-Rosa, PAYRATó Lluís (Eds.), La gramática i la semántica en l'estudi de la variació, Barcelona: PPU - Universitat de Barcelona, $59-112$.

BOLINGER Dwight Le Merton, 1950, "Rime, Assonance, and Morpheme Analysis”, Word, n 6, 117-136.

BOOTH Michael, 2017, Shakespeare and conceptual blending: cognition, creativity, criticism, Cham, Switzerland: Palgrave Macmillan.

BRDAR-SZABO Rita, BRDAR Mario, 2008, “On the marginality of lexical blending”, Jezikoslovje, n 9.1/2, 171-194.

BRYANT Margaret M., 1974, “Blends are increasing”, American Speech, n 49.3/4, 163-184.

CANNON Garland, 1986, “Blends in English word formation”, Linguistics, n 24.4, 725-753.

CANNON Garland, 2000, "Blending”, in BOOIJ Geert, LEHMANN Christian, MULGDAN Joachim, in collaboration with KESSERLHEIM W. and SKOPETEAS S. (Eds.), Morphology. An International Handbook on Inflection and Word-Formation, Volume 1, Berlin/New York: Walter de Gruyter, 952-956. 
CLARK Brady, KAUFMANN Stefan, SAGI Eyal, 2009, “Semantic density analysis: comparing word meaning across time and phonetic space”, in PENNACCHIOTTI Marco (Ed.), Proceedings of the Workshop on Geometrical Models of Natural Language Semantics (GEMS '09), Association for Computational Linguistics, Stroudsburg, PA, USA, 104-111. Accessed online at https://dl.acm.org/ citation.cfm?id=1705429.

CHO Eun Jung, 2019, “A Cognitive Approach to Productive Word-Formation in Neologisms: Focusing on -gate Words", The Journal of Modern British \& American Language \& Literature, Volume $37, \mathrm{n}^{\circ} 1$.

CONNOLLY Patrick, 2013, “The innovation and adoption of English lexical blends", JournaLIPP, ${ }^{\circ}$ 2,1-14.

CRYSTAL David, 1995, The Cambridge Encyclopedia of the English Language, Cambridge; New York; Melbourne: Cambridge University Press.

DE CUYPERE Ludovic, 2008, Limiting the Iconic: From the Metatheoretical Foundations to the Creative Possibilities of Iconicity in Language, Amsterdam: Benjamins.

DEVEREUX Robert, 1984, “Shortenings, blends and acronyms”, Word Ways, n 17, 210-215.

DRELLISHAK Scott, 2006, "Statistical techniques for detecting and validating phonesthemes", LSA Annual Meeting, Anaheim, CA.

ELDRIDGE Alison, 2011, “Groupon: American company”, Encyclopædia Britannica, Inc. Accessed online at https://www.britannica.com/topic/Groupon.

EK Adam, 2018, "Blending Words or: How I Learned to Stop Worrying and Love the Blendguage: A computational study of lexical blending in Swedish", Stockholm University [thesis].

Extell.com, 2017, “Team”, Brooklyn Point. Accessed online at https://brooklynpointnyc.com/ team.

FANDRYCH Ingrid, 2008, "Pagad, chillax and jozi: A multi-level approach to acronyms, blends and clippings", Nawa Journal of Language and Communication, $\mathrm{n}^{\circ} 2.2,71-88$.

FAUCONNIER Gilles, TURNER Mark, 2002, The Way We Think: Conceptual Blending and the Mind's Hidden Complexities, New York: Basic Books.

FUSTER MÁRQUEZ Miguel, 2008, Working with Words: An Introduction to English Linguistics, Publicacions de la Universitat de València.

GLYNN Dylan, 2014, “Correspondence analysis. An exploratory technique for identifying usage patterns" GLYNN Dylan, ROBINSON Justyna A. (Eds.), Corpus Methods for Semantics. Quantitative Studies in Polysemy and Synonymy, Amsterdam: John Benjamins, 133-179.

Google Books Ngram Viewer, 2013, Google. Accessed online at https://books.google.com/ngrams. GOMOLA Aleksander, 2018, Conceptual blending in early christian discourse: a cognitive linguistic analysis of pastoral metaphors in patristic literature, Berlin: De Gruyter.

GRADY Joseph E., OAKLEY Todd, COULSON Seana, 1999, "Blending and Metaphor", Markturner.org. Accessed online at http://markturner.org/blendaphor.html on 23/05/2019.

GRIES Stefan Th., 2004, “Isn't that Fantabulous? How similarity motivates intentional morphological blends in English", in ACHARD Michael, KEMMER Suzanne (Eds.), Language, culture and mind. Stanford, CA: Center for the Study of Language and Information (CSLI), 415-428. 
GRZEGA Joachim, SCHÖNER Marion, 2007, English and General Historical Lexicology: Materials for Onomasiology Seminars, Katholische Universität Eichstätt-Ingolstadt.

HAUSMANN Franz Josef, 1977, Einführung in die Benutzung der neufranzösischen Wörterbücher, Romanistische Arbeitshefte 19, Tübingen, Max Niemeyer Verlag.

HAUSMANN Franz Josef, 1989, “Die Markierung im allgemeinen einsprachigen Wörterbuch: eine Übersicht”, in HAUSMANN Franz Josef, REICHMANN Oskar, WIEGAND Herbert Ernst, ZGUSTA Ladislav (Hrsg.), 1989-1991, Wörterbücher / Dictionaries / Dictionnaires. Ein internationales Handbuch zur Lexikographie / An International Encyclopedia of Lexicography / Encyclopédie internationale de lexicographie, 3 vol., Berlin / New York, Walter de Gruyter, volume 1, article $53,649-657$.

HOLDER R.W., 1995, A Dictionary of Euphemisms, Oxford: Oxford University Press.

KELLY Michael H., 1998, “To ‘brunch' or to ‘brench': Some aspects of blend structure”. Linguistics, $\mathrm{n}^{\circ} 36,579-590$.

LEHRER Adrienne, 2007, "Blendalicious", in MUNAT Judith (Ed.), Lexical Creativity, Texts, and Contexts, Amsterdam; Philadelphia: Benjamins, 115-133.

LEPIC, Ryan, 2016, "Lexical blends and lexical patterns in English and in American Sign Language". Proceedings of the Mediterranean Morphology Meetings, North America, 10 September 2016. Accessed online at http://resmicte.lis.upatras.gr/index.php/mmm/article/ view/2728 on $23 / 05 / 2019$.

LÓPEZ RÚA Paula, 2004, “The categorial continuum of English blends”, English Studies, n 86.1, 63-76.

MATTIELLO Elisa, 2013, Extra-grammatical morphology in English: abbreviations, blends, reduplicatives, and related phenomena, De Gruyter.

MILLER Gary, 2014, English Lexicogenesis, Oxford: Oxford University Press.

NEVEU Franck, 2011a (2000), Lexique des notions linguistiques, $2^{\text {nd }}$ edition, Armand Colin.

NEVEU Franck, 2011b (2004), Dictionnaire des sciences du langage, $2^{\text {nd }}$ edition, Armand Colin.

O'GRADY William, DOBROVOLSKY Michael, KATAMBA Francis, 1996 (1987), Contemporary Linguistics: an Introduction, $3^{\text {rd }}$ edition, Copp Clark Pitman Ltd.

OTIS Katya, SAGI Eyal, 2008, "Phonaesthemes: A corpora-based analysis" in LOVE Bradley C., MCRAE Ken, SLOUTSKY Vladimir M. (Eds.), Proceedings of the $30^{\text {th }}$ Annual Meeting of the Cognitive Science Society, Austin, Texas: Cognitive Science Society, 65-70.

PLAG Ingo, 2003, Word-Formation in English, Cambridge: Cambridge University Press.

REAY Irene Elizabeth, 2009 (1994), “Sound symbolism”, in ALLAN Keith (Ed.), Concise Encyclopedia of Semantics, Oxford: Elsevier, 893-901.

RENNER Vincent, 2015, “Lexical blending as wordplay”. Accessed online at https:// www.academia.edu/19466742/Lexical_blending_as_wordplay.

RENNER Vincent, MANIEZ François, ARNAUD Pierre Jean-Louis, 2012, Cross-Disciplinary Perspectives on Lexical Blending, Berlin; Boston: De Gruyter.

SANCHEZ-STOCKHAMMER Christina, 2018, English Compounds and their Spelling, Cambridge: Cambridge University Press.

SMITH Christine Anne, 2013, "The dysphemistic euphemism implied in unVables such as unmentionables, unprintables, undesirables", Lexis, $n^{\circ} 7,121-143$. 
SMITH Christine Anne, 2014, "The phonesthetics of cognitive blends in the OED”, ExCELL, n².1, 12-45. Accessed online at https://www.researchgate.net/publication/ 283624556_The_phonesthetics_of_cognitive_blends_in_the_OED.

The Collins English Dictionary, 2019, Collins. Accessed online at https:// www.collinsdictionary.com/dictionary/english.

The Freelance Studio, 2016, "Noted: New Logo for Funimation”, The Freelance Studio Accessed online at http://www.thefreelancestudio.com/journal/tag/api/page/757.

The Oxford Dictionary of English, 2019, Oxford: Oxford University Press. Accessed online at https://en.oxforddictionaries.com/english.

The Oxford English Dictionary, 2018, Oxford: Oxford University Press. Accessed online at http:// www.oed.com.ressources.univ-poitiers.fr.

TOURNIER Jean, 1985, Introduction Descriptive à la Lexicogénétique de l'Anglais Contemporain, Paris; Genève: Champion-Slatkine.

TOURNIER Jean, 2004, Précis de Lexicologie Anglaise, Paris: Ellipses Edition Marketing SA.

TURNEY Peter D., PANTEL Patrick, 2010, “From frequency to meaning: Vector Space Models of semantics”, Journal of Artificial Intelligence Research, $n^{\circ} 37,141-188$.

Urban Dictionary, 1999-2019. Accessed online at http://www.urbandictionary.com.

VAN DER HULST Harry, 2008, Linguistic Structures, Dubuque, Iowa: Kendall Hunt Publishing Company.

\section{NOTES}

1. The word "splinter" needs clarifying as it may adopt various meanings according to the author who uses the term. It may simply refer to any "shorter substitutes" of words (Adams 1973 : 142), more specifically to the parts of the source words that are preserved in the blend (e.g. Adams 1973 ; Beliaeva 2014 : 4 ; Fandrych 2008 ; López Rúa 2004), even more restrictively to certain word parts which are productive in creating new words, such as -(a)holic or -(a)nomics (Bauer 2006: 503 ; Beliaeva 2014 : 4), or to "bound morphemes such as (...) nomics (from economics), which originated in blend formations" (Bauer 2004 ; Renner, Maniez, Arnaud 2012 : 2). In the present paper, a "splinter" is defined as a clipped submorphemic component form of a source word which is retained in a composite word, either in clipped compounds or blends. This is why clipped compounds and blends are here both labelled as "splinter combinatives". In such formations, the combinations, just like the splinters that are employed, are still bound to their unclipped etyma, so that a speaker or writer still thinks about the unclipped source words. The more a splinter is productive and commonplace, the more it turns into a combining form, i.e. a morpheme, as part of a complex word: this is what is called the "secretion" (Mattiello $2013: 34$ ) of morphemes (or combining forms) from splinters. A secretion of the combining form -aholic originated from the apheresis of alcoholic and the production of many words such as computerholic, newsaholic or spendaholic (OED Online 2018, s.v. “-aholic") first thought of as blends when <aholic $>$ was a splinter bound to its unclipped source word alcoholic, and then as complex words once the form <aholic> was secreted, i.e. became independent from its source word. Cho (2019) suggests the term "remnant" so as to specifically identify a morpheme which stems from an independent splinter. "Abbreviated combining forms" like eco- from ecology and producing eco-art or eco-activist are "borderline cases between splinters (with no morpheme status) and 
combining forms" (Mattiello $2013: 35$ ). They testify to the "gradual process" that occurs from a productive splinter becoming a morpheme (Beliaeva $2014: 5$ ).

2. The etyma of a blend are put in parentheses throughout this paper.

3. This definition makes the distinction between compounding and blending: it includes in the category of blends all splinter combinatives which are not clipped compounds. Other conflicting views for the definition of blends are not expounded here. For an overview of different defining features, see Renner 2015 : 122. Renner's definition of a lexical blend is inclusive, taking the various traits in the conflicting views not as defining features, but as typicality features (Renner $2015: 122)$.

4. Miller relates it to the broader notion of expressivity, encompassing more or less conscious playful coinages with clearly conscious word play in various word-formation processes (Miller $2014: 240)$.

5. Google Books (2019), Google Books Ngram Viewer (2013), Google Scholar (2019), Oxford Dictionaries (2019), Oxford English Dictionary online (2018) and Urban Dictionary (2019).

6. Among blends, a pun constitutes a subcategory defined as any blend overlapping all of one of the base forms with at least part of another (Algeo $1977: 50$ ).

7. Cannon explains that "[t]he paired source words which have provided the blends often have rather similar meanings, but are never synonyms" (1986: 746). It is generally accepted that perfect synonyms do not exist, and that what is called "synonym" is actually a very close synonym, i.e. a word with a similar, almost identical meaning. However, "near synonyms" may refer to words whose meanings are quite similar but more different than "synonyms".

8. In order to include all the possibilities of word play in blends, it is important to choose terms such as "source" words or "input" words, but not "base" words or "etyma", because the playfulness of a blend may rely on its homophony with another attested word (and therefore not exclusively on an association of the etyma, in such cases).

9. Mattiello (2014 : 139) refers to a semantic salience applying to the order of the component words; among other criteria, the most salient source word occurs in head position, as in wintertainment where entertainment is the head. Semantic salience is related to motivation, not purpose.

\section{ABSTRACTS}

The motivation of playful blending is circumscribed by the combination of source words with a recognized linguistic similarity (either semantic or morphological), or an oxymoronic effect. Interlocutors may then remotivate the consonant clusters of these forms, if they associate semantic features to them so as to coin other blends.

The use of playful blending is aimed at reinforcing cognitive salience (a heightened attention is needed to read the output form). The output form therefore stands out from its environing text of monomorphemic lexemes, derivatives and unclipped compounds. It changes the way one focuses on a referent, either by emphasizing a lexeme which is given high attention, or minimizing its impact on the audience who has to reconstitute the possibly unpleasant source words mentally. This main approach unveils a tree of possible purposes (illustrated with representative samples of data), among which are humour, commercial attractiveness, witticisms to defend an idea, literary aestheticism, euphemism, dysphemism, or idiosyncrasy to be creative or express one's individuality. 
Coreferential forms inside and outside playful blending are examined in corpus-based tools, which demonstrates that purpose is utterance-based (i.e. purely pragmatic). Utterances of the same playfully blended forms are analysed in various situations, which proves that while motivation is usage-based and situated on the semantic-pragmatic interface. However, pragmatics sometimes has to take over semantics' limits to shed light on the motivation of a blend, since the form may remain ambiguous.

La motivation de l'amalgamation de jeu de mots se circonscrit à la combinaison de lexèmes source cognitivement reconnus comme ayant une similitude linguistique (qu'elle soit sémantique ou morphologique), ou un effet d'oxymore. Il est possible que les interlocuteurs remotivent ensuite des groupes de consonnes de ces formes, s'ils leurs associent des traits sémantiques pour former d'autres amalgames.

L'amalgamation de jeu de mots est destinée à renforcer la saillance cognitive (une attention accrue est requise pour la réception de la forme produite). La forme produite se démarque alors de son cotexte essentiellement composé de lexèmes monomorphémiques, de dérivés et de composés non-tronqués. Cela change la façon dont on se focalise sur un référent, que ce soit par la mise en relief d'une lexie sur laquelle on attire l'attention, ou par la réduction de son impact sur les interlocuteurs qui doivent reconstituer mentalement les éléments sources possiblement gênants. Cette approche principale dévoile une arborescence d'objectifs possibles (illustrée avec un échantillon de données représentatives), comprenant l'humour, l'attractivité commerciale, les mots d'esprits pour défendre ses idées, l'esthétisme littéraire, l'euphémisme, le dysphémisme, ou l'idiosyncrasie pour exprimer son individualité ou paraitre original et créatif.

L'examen de formes coréférentielles au sein ou en dehors de l'amalgamation de jeu de mots démontre que l'objectif repose sur l'occurrence (est purement pragmatique). L'analyse, dans des situations variées, d'occurrences de mêmes formes amalgamées par jeu de mots prouve que la motivation repose sur l'usage et se trouve sur l'interface sémantique-pragmatique. Cependant, la pragmatique doit parfois prendre le relais des limites de la sémantique pour mettre en lumière la motivation d'une forme amalgamée, puisque la forme peut rester ambigüe.

\section{INDEX}

Mots-clés: Amalgamation, amalgames ludiques, jeu de mots, motivation, objectif, saillance cognitive, euphémisme, dysphémisme.

Keywords: Blending, playful blending, word play, motivation, purpose, cognitive salience, euphemism, dysphemism.

\section{AUTHOR}

\section{BORIS LEFILLIÂTRE}

Université de Caen

Laboratoire FORELLIS/Université de Poitiers 